\title{
Ostreid herpes virus 1 infection in families of the Pacific oyster, Crassostrea gigas, during a summer mortality outbreak: Differences in viral DNA detection and quantification using real-time PCR
}

\author{
Christopher Sauvage ${ }^{a}$, Jean François Pépin ${ }^{a}$, Sylvie Lapègue $^{a}$, Pierre Boudry $^{b}$ and Tristan Renault $^{\mathrm{a},{ }^{\star}}$ \\ a Ifremer, Laboratoire de Génétique et Pathologie, Avenue Mus de Loup, 17390 La Tremblade, France \\ ${ }^{\mathrm{b}}$ Ifremer, UMR M100 Physiologie et Ecophysiologie des Mollusques Marins, Technopôle de Brest-Iroise, 29280 \\ Plouzané, France
}

*: Corresponding author : T. Renault, Phone: +33(0) 5467626 10, Fax: +33(0) 5467626 11, email address :

\begin{abstract}
:
Ostreid herpes virus 1 (OsHV-1) infections, notably reported in Europe and the USA, are closely associated with significant mortalities of the Pacific oyster, Crassostrea gigas, especially during its early stages of life. In summer 2006, we monitored mortality by strict daily verification of three full-sib families of oysters reared under common conditions. We quantified OsHV-1 using real-time PCR in dead and living individuals during and after a mortality event. Mortality events were severe and brief, but significantly different between tested families (cumulative mortality ranging from 1.2 to $49 \%$ ). Realtime PCR assays revealed different viral DNA loads in dead individuals from different families $(P<$ $0.001)$. Moreover, the mean level of infection among families was correlated with mortality $(P<0.05)$. Living oysters showed a significantly lower amount of viral DNA compared with dead ones. This is the first experiment showing the daily changes of individual OsHV-1 DNA load during a mortality outbreak. Our results also support the previously reported high genetic basis underlying the variance of resistance of Pacific oyster to summer mortality, suggesting that there might be a possibility to improve resistance to OsHV-1 by selective breeding.
\end{abstract}

Keywords: Crassostrea gigas; Mortality; OsHV-1; Real-time PCR; Viral DNA quantification 


\section{Introduction}

Pacific oyster (Crassostrea gigas) production on the French coasts has experienced periodic mass mortalities during the summer months for at least 20 years (Renault et al., 1994; Goulletquer et al., 1998; Soletchnik et al., 1999, 2007). This syndrome is known as 'summer mortality' and as been reported in most Pacific oyster producing countries, such as Japan, USA and Australia. The first description of this phenomenon was made in the 1940s in Japan, where C. gigas is endemic. According to Koganezawa (1974), the mortality outbreaks began occurring in 1945 with the largescale use of hanging culture methods. In the late 1950s, C. gigas mortality episodes were also reported on the West coast of the USA (Glude, 1974 in Cheney et al., 2000), where C. gigas had been imported for aquaculture production. These mortality outbreaks had many of the same features as those observed in Japan (Koganezawa, 1974). A summer mortality episode in Alaska in 1987 involved unusually high temperatures $\left(-20^{\circ} \mathrm{C}\right)$ for this area (Meyers et al., 1990).

In France, factors such as food limitation, oxygen depletion, salinity and temperature variations do not appear to act alone as single direct causative factors of the summer mortality syndrome (Soletchnik et al., 1998, Ropert et al., 2008). It has been suggested that mortality outbreaks occurring in $C$. gigas are the result of multiple factors or stressors, including elevated temperatures, physiological stress associated with maturation, aquaculture practices, pathogens or pollutants (Goulletquer et al., 1998; Samain and McCombie, 2008). Although efficient defence mechanisms normally help to limit the proliferation of pathogens in oysters (Harris-Young et al., 1995; Cheng, 1996), because they are benthic filter-feeders they are permanently exposed to pathogens and are therefore vulnerable to such mortality risks.

A multidisciplinary project known as 'Morest' was recently conducted in France, including studies on genetics, physiology, immunology and pathology, to improve our understanding of the causes of summer mortality in oysters (Samain and McCombie, 2008). This project notably studied the complex interactions between environmental factors, oysters and pathogens, including a herpes virus (Renault et al., 1994) and different species of bacteria belonging to the genus Vibrio (Le Roux et al., 2002; Le Roux et al., 2004; Labreuche et al., 2005, Garnier et al., 2007). A high heritability of resistance to summer mortality was demonstrated (Dégremont et al., 2005, 2007), and divergent selection for survival was performed over several generations (Boudry et al. 2008). Interestingly, high ("R": Resistant) and low ("S": Susceptible) selected lines showed a differential pattern for reproduction, with $\mathrm{S}$ groups investing more in reproduction and/or delaying spawning for a longer time than $\mathrm{R}$ groups (Samain et al., 2007). These results agree with those obtained in the USA (Beattie et al., 1980), supporting the hypothesis that gonad maturation and loss of carbohydrate reserves are involved in summer mortality (Perdue et al., 1981).

Herpes-like viruses have been detected during summer mortality outbreaks in France (Renault et al., 1994; Nicolas et al., 2008) and in the USA (Friedman et al., 2005; Burge et al., 2007). Because of the economic importance of oyster aquaculture, molecular diagnostic tools were developed to detect these viruses (Renault and Lipart, 1998; Renault et al., 2000; Arzul et al., 2002; Lipart and Renault, 2002) based on the complete genome sequence of the virus infecting $C$. gigas in France (ostreid herpes virus 1, OsHV-1) obtained by Davison et al. (2005). Recently, the development of a real-time PCR assay provided a method of quantifying OsHV-1 DNA (Pépin et al., 2008). This new diagnostic tool offers new opportunities for the study of viral replication mechanisms, management of the disease or selective breeding.

In summer 2006, an experiment was performed to investigate the daily kinetics of summer mortality in full-sib families of oysters. The experiment was designed as part of a study of the genetic basis resistance. We quantified OsHV-1 DNA using real-time PCR in live and dead juveniles from three oyster families sampled during the survey and in individuals surviving to the end of the experiment. Viral DNA detection was first carried out in 3 different tissues (mantle, digestive gland and adductor muscle) from a number of individuals in order to assess the best organ for viral detection. Using real-time PCR, we characterized and quantified viral load as the number of viral DNA copies per mg of fresh tissue. This allowed us to investigate the daily kinetics of the viral infection before, during and after the mortality outbreak. 


\section{Materials and methods}

\subsection{Oysters}

The mating design relied on three successive generations (F0, F1 and F2). The F0 individuals were sampled within the third generation of the divergent selective breeding lines for survival (G3R and G3S), showing contrasted survival to summer mortality both in the field and in laboratory experiments (Boudry et al., 2008). For each generation, reproduction of oysters was performed as follows. To induce gametogenesis, oysters were placed in a favourable environment for reproductive maturation, with an enriched diet of algae and gradual increase of water temperature to reach $22-24^{\circ} \mathrm{C}$ during the first four weeks of a total conditioning period of 12 weeks. At the end of this period, the maturation of gametes was assessed by photonic microscopy. When fully mature, gametes were obtained by scarification of the gonads and were filtered and counted. These gametes were mixed in a volume of $500 \mathrm{~mL}$ filtered seawater at a ratio of 100 spermatozoids per oocyte (Boudry et al., 2002) to fertilize 3 millions eggs for each cross. Then, 3 hours postfertilisation, fertilized eggs were transferred to a rearing room and put in $30 \mathrm{~L}$ tanks with water temperature maintained around $24^{\circ} \mathrm{C}$. Oysters were reared during their larval stage without any selective culling (i.e. no sieving to discard smallest individuals), following the protocol described in Taris et al. (2006). On the 28 July 2004, bi-parental crosses, were performed in the Ifremer experimental research station of the Invertebrate Physiology Laboratory in Argenton (Finistère, France) between eight F0 individuals from the low ("S") and high ("R") selected lines, to produce F1 hybrid families. Following settlement and metamorphosis, when oysters reached a minimal size of $2 \mathrm{~mm}$ they were transferred to the Ifremer nursery in Bouin (Vendée, France). Families were placed for 12 weeks in high-growth environmental conditions with an enriched diet of the alga Skeletonema costatum (Baud and Bacher, 1990). Following the same protocol, F1 individuals were crossed with another one to produce three $F 2$ families $\left(R^{\star} O, Z^{\star} A C\right.$ and $\left.B^{\star} X\right)$. These $F 2$ crosses were performed at the Ifremer experimental hatchery of the Ifremer Genetics and Pathology Laboratory in La Tremblade (Charente Maritime, France) on the 22 February 2006 (day 0). Juveniles were sampled when their size ranged from 16 to $60 \mathrm{~mm}$. This range of size is usually sufficient to obtain enough fresh tissue from dead individuals to extract nucleic acids. The mortality monitoring experiment started on July 8 (i.e. 138 days after fertilization) and was ended 86 days later (October 15, day 224), once no more mortality had been observed for several weeks.

\subsection{Experimental design to investigate the kinetic of summer mortality}

On 29 June 2006 (day 128), three groups of 1500 juveniles, randomly sampled within each family, were placed in a single $30 \mathrm{~m}^{3}$ raceway, in the experimental facilities of the Ifremer Genetics and Pathology Laboratory. Seawater temperature was automatically recorded every 10 minutes during the course of the experiment using a multi-parametric in situ monitoring system (YSI 6920S). The water inflow rate corresponded to two total renewals of the raceway water per day. Individuals were put in standard oyster-growing bags (6mm mesh) as follows: (i) one thousand oysters were put in a first bag where dead oysters were removed daily for study (ii) five hundred individuals were placed in a second bag from which 30 different living juveniles (as our protocol is destructive) were sampled daily during the first four weeks of the monitoring and then twice a week until the end of the experiment. The bags of oysters were randomly arranged on iron racks at $40 \mathrm{~cm}$ height above the bottom, as is the commonly practice used in oyster aquaculture in the field, and were turned over every week to avoid algal development and subsequent feed depletion.

Prior to the beginning of the experiment (day 128), a set of 96 individuals was first assessed by real-time PCR to evaluate the viral prevalence of OsHV-1. During the experiment, bags were checked daily to remove dead oysters, which were stored immediately at $-20^{\circ} \mathrm{C}$ to conserve DNA for later extraction if a sufficient amount of tissue remained. Dead oysters could be identified by their open valves, and mortality was quantified daily by counting the number of individuals that had died.

Individual viral quantifications were performed by real-time PCR for (i) the first 150 individuals that died in each of the two families where significant mortality occurred (i.e. families $R^{\star} O$ and $Z * A C$ ), (ii) 12 of the 30 living individuals sampled daily from each of the three families during the mortality outbreak, (iii) 150 individuals per family that had survived through the mortality outbreak to day 
224. We were careful to sample the same type of tissue on dead, living and surviving oysters to allow the direct comparison of the viral load and reduce variance in its measurement as much as possible.

\subsection{OsHV-1 detection and quantification using real-time PCR}

Total DNA was extracted using the Qiagen Qiamp ${ }^{\circledR}$ tissue mini kit according to the manufacturer's protocol and as previously reported by Robledo et al., (2000). The DNA quality was firstly checked by spectrophotometry (Eppendorf ${ }^{\circledR}$ ) and run on a $1.5 \%$ agarose gel. Low quality $\left(\mathrm{DO}_{260 / 280}>1.8\right)$ and quantity $\left(<50 \mu \mathrm{g} \cdot \mathrm{LL}^{-1}\right)$ DNA samples were removed and replaced by another one for the following steps.

The real-time PCR protocol applied for OsHV-1 DNA detection and quantification has been published recently (Pépin et al., 2008). Briefly, DNA samples were diluted to a concentration of 2 ng. $\mu \mathrm{L}^{-1}$. The reaction mix was composed of $5 \mu \mathrm{L}$ total DNA sample, $12.5 \mu \mathrm{L}$ Full-Velocity ${ }^{\circledR}$ SYBR Green Master Mix reagent (Stratagene), $2.5 \mu \mathrm{L}[2 \mu \mathrm{M}]$ forward (C9) and reverse primers (C10), and $2.5 \mu \mathrm{L}$ distilled water, in a final reaction volume of $25 \mu \mathrm{L}$. The primer pair generates a $197 \mathrm{bp}$ amplicon and targets the $C$ region of the viral genome (Barbosa-Solomieu et al., 2004). Amplifications were performed in 96-well plates on a Mx3000P real-time PCR thermocycler sequence detector (Stratagene), according to the following conditions: initial denaturation $1 \mathrm{~min}$ at $95^{\circ} \mathrm{C}$, followed by 40 cycles of $15 \mathrm{~s}$ at $95^{\circ} \mathrm{C}$ and $30 \mathrm{~s}$ at $60^{\circ} \mathrm{C}$. The specificity of the PCR products was systematically checked with the melting temperature $(\mathrm{Tm})$ value from the dissociation curve (Bustin, 2000). The quantification of the samples was based on a standard five-fold dilution curve derived from a stock solution of OsHV-1 genomic DNA $\left(5.10^{6}\right.$ copies. $\left.\mathrm{L}^{-1}\right)$ extracted from purified virus particles (Le Deuff and Renault, 1999). Efficiency $(E)$ and linearity $\left(R^{2}\right)$ were calculated from the standard curve with MxPro v3.0 software (Stratagene), and tested for each run. All samples were analysed in triplicate.

Individual viral DNA quantification was first performed on a set of seven individuals that died during a previous mortality event associated with OsHV-1 infection, using mantle, digestive gland and adductor muscle to study the variance in real-time PCR viral DNA quantification among these different tissues. As a second step, the viral DNA was individually quantified in mantle from three types of individuals (i.e. dead, living and surviving) for each family. The results were expressed as a $\log _{10}$ of the viral DNA copy number per mg of tissue.

\subsection{Statistical analysis}

Descriptive statistics on individual viral DNA quantification data were carried out using SPSS v11.5 statistical software. The normality of the data was tested using a Shapiro-Wilk test. A nonparametric Kendall $W$ test was used to investigate the differences in viral DNA quantification between the different types of tissue, and a non-parametric Kruskal-Wallis test was performed to analyse the differences in variance of viral DNA quantities between (1) tissues, (2) families and (3) the type of individuals (dead, living or surviving). A Spearman rho test was used to analyse the correlation between viral DNA quantification and mortality data. $\mathrm{P}$ values lower than 0.05 were used to identify significant effects or differences.

\section{Results}

\subsection{Oyster mortality and seawater temperature}

No significant mortality was recorded prior to day 138 . High mortalities were then observed on day 139 (Fig. 1). Cumulative mortality over the twelve following weeks ranged from 1.2 (family $B^{\star} X$ ) to $49 \%$ (family $Z * A C$ ) and was significantly different between families $(p<0.001)$. Mortality was sudden, as more than $60 \%$ of dead individuals were observed during the first week of the survey and very little mortality was observed after day 159 (Fig. 1). During the mortality outbreak (day 139 
to 159$)$, the mean seawater temperature $\left( \pm \mathrm{SD}\right.$ ) was $23.8 \pm 1.02^{\circ} \mathrm{C}$, ranging from 21.5 and $26.8^{\circ} \mathrm{C}$ (Fig. 1).

During the experimental monitoring period, mean water temperature was not significantly different from temperatures observed in other years. However, it should be noted that the outbreak was preceded by an increase in the seawater temperature of $2.3^{\circ} \mathrm{C}$ over two days.

\subsection{Detection of OsHV-1 and individual viral quantification}

Quantification of viral DNA was optimised by first comparing viral detection obtained after DNA extraction from different tissues sampled from oysters that died during a previous mortality event associated with OsHV-1 infection. A comparison was made between adductor muscle (AM), mantle (M) and digestive gland (G). Pieces of the different tissues ranging from 20 to $25 \mathrm{mg}$ were precisely weighed to allow the viral DNA load of individuals to be estimated as the number of viral genomic DNA copies per milligram of tissue. A sample of $20-25 \mathrm{mg}$ represents $6 \%$ o to $1.5 \%$ of the total fresh weight, depending the size of the individual $(2-4 \mathrm{~g})$. The comparison among three different tissues did not show any significant differences $(\mathrm{W}=8.97 ; \mathrm{P}>0.05)$. The viral load was estimated as $1.0310^{8} \pm 7.6710^{7}, 1.1510^{8} \pm 8.5010^{7}$ and $9.7910^{7} \pm 7.2610^{7}$ viral DNA copies.mg ${ }^{-1}$ in the adductor muscle, mantle and digestive gland tissues, respectively. We therefore decided to extract nucleic acids from a single tissue only during the mortality experiment, and chose mantle because the amount of this tissue remaining on dead individuals is usually sufficient to achieve reliable DNA extraction.

The raw data obtained from the analysis of samples were carefully examined to verify that $\mathrm{Ct}$ values (Cycle threshold) obtained had the correct Tm value corresponding to the amplicon. This method allows incorrect PCR amplification to be detected visually. The detection of OsHV-1 in the set of 96 randomly chosen individuals prior to the experiment (day 128) did not reveal any significant viral infection. Only three of these animals displayed positive detection results, with viral DNA copies. $\mathrm{mg}^{-1}$ inferior to $1.10^{3}$.

In our experiment, the virus was detected in both living and dead individuals. In dead individuals, the prevalence was estimated as $94.7 \%(142 / 150)$ and $95.3 \%(143 / 150)$ in the $R^{\star} O$ and $Z * A C$ families, respectively. In living individuals, the prevalence ranged from $9.4 \%$ (9/96 - $B^{\star} X$ family) to 83.2\% (89/107 - Z*AC family). Qualitative data for OsHV-1 detection on the three oyster families and associated prevalence are presented in Table 1.

The individual viral load was significantly different between dead, living and surviving oysters $(P<0.001)$. In dead individuals, the viral load showed a high variance both between families and within each family $(P<0.001-$ Table 2$)$. The highest level of infection was detected in dead animals of the $Z * A C$ family $(Z=27.25 ; P<0.001)$ with a mean viral load estimated at $1.1410^{7}$ DNA copies $\mathrm{mg}^{-1}$ (Fig. 2). In the 20 individuals of the $B^{\star} X$ family that died during the experiment, quantitative data could not be estimated because the amount of tissue remaining in the dead oysters was not sufficient to extract viral DNA. In living individuals, the average viral load showed no significant difference between families $(P=0.07)$ but was highly variable, especially in the $Z * A C$ family where it ranged from 0 to $1.1010^{8}$ DNA copies $\mathrm{mg}^{-1}$ tissue. The lowest mean level of infection was observed in the $B^{\star} X$ family with $2.510^{2}$ DNA copies $\mathrm{mg}^{-1}$ of tissues. In individuals that survived to the end of the experiment, the viral load was significantly lower from that observed in dead and living individuals sampled during the experiment $(\mathrm{P}<0.001)$, but there was no significant difference between the three families $(P=0.069)$. The highest and lowest levels of quantification were detected in the $R^{*} O$ and $B^{*} X$ families with $3.3410^{2}$ and $1.0210^{2}$ copies of viral DNA mg ${ }^{-1}$ of tissue, respectively (Table 2). The correlation between the level of mortality that occurred in families and the mean level of OsHV-1 DNA detection was highly significant (Spearman's $\rho=0.338 ; \mathrm{P}<0.001$ ).

\section{Discussion}

4.1 Factors involved in oyster mortality 
The present experiment was designed to monitor oyster mortality and sample live and dead individuals on a daily basis. Furthermore, oysters were reared under common environmental conditions throughout their lives, including when mortality occurred. This allowed individual viral DNA loads to be recorded daily, thus providing a measure of the viral infection level that could be compared between dead, living and surviving oysters, and also within and between families. The fact that the mortality episode occurred very suddenly suggests that an infectious agent, such as OsHV-1, may be the causal factor. Similarly, Burge et al. (2006) observed a comparable temporal pattern in mortality of Pacific oysters reared in the field along the West coast of the USA. In this study, mortalities ranged from 5.7 to $64 \%$ during a 12 days period. Although our experiment might not fully reflect environmental conditions in the field, our results are likely to be relevant to summer mortality observed in field conditions (Burge et al., 2006).

Additionally, a positive effect of high temperature on OsHV-1 infection have also been reported, notably in hatchery-reared larvae of Pacific oyster (Le Deuff et al., 1996). Our monitoring of the seawater temperature supports these results, as do those reported by Burge et al. (2006). A higher temperature influences the expression of herpes virus by promoting an earlier production of viral particles, resulting in a rapid spread of the disease that could be capable of causing sudden and massive mortalities. OsHV-1 may thus usually act in synergy with environmental parameters, particularly temperature, to affect oysters (Moal et al., 2008). In our experiment, the mortality outbreak occurred after a $2^{\circ} \mathrm{C}$ increase in seawater temperature. The two-day delay before the mortality outbreak may reflect the time required for the virus to initiate an intense replication phase. In the following days, when massive mortality was occurring, seawater temperature reached $23.8^{\circ} \mathrm{C} \pm 1.02^{\circ} \mathrm{C}$. This clearly illustrates that temperature is one of the major factors acting on the mechanisms of OsHV-1 infection. Interestingly, temperature is also one of the main factors involved in gametogenesis in the Pacific oyster (Fabioux et al., 2005). In autumn (i.e. after the reproductive period), decreasing water temperature may be related to the observed decrease in viral load in oysters and absence of mortality. Temperature is clearly a significant factor related to mortality outbreaks, but it is not the only one (as notably documented by Samain et al., 2008). Significant correlations are found between water temperature gametogenesis, physiological and immunological weakening, prevalence of pathogens, and oyster mortality. A similar relationship was also demonstrated in the infection of the eastern oyster by the parasite Perkinsus marinus (Ragone Calvo et al., 2003).

\subsection{Quantification of OsHV-1 DNA}

A number of different techniques (PCR, ISH and immunochemistry) were employed to detect OsHV-1 in 30 asymptomatic individuals of the Pacific oyster, Crassostrea gigas in a previous study by Arzul et al. (2002). This study used different types of tissue from adult oysters for OsHV-1 detection. When mantle and gill tissues were used, $>76 \%$ of individuals tested positive whereas, when gonadic tissue was used, OsHV-1 was detected in a far less significant number of individuals (33\%, Arzul et al., 2002). To further examine the hypothesis of differential viral load between tissues, we compared the OsHV-1 in three types of tissue (mantle, digestive gland and adductor muscle), this time taken from infected animals. The gonadic tissue was not analysed due to the young age of the oysters ( $<1$ year). Although gametogenesis can be significant in one-year old oysters, it is usually more limited and variable than in older individuals. As a result, this tissue is also harder to sample from one-year-old oysters than the tissues we tested. Furthermore, the oysters in our study did not present mature gonads during the sampling period. Very few quantitative data are yet available regarding OsHV-1 infection in oysters (Renault et al., 2004), which may partly be due to the lack of cell lines in bivalve molluscs on which to cultivate this infectious agent. Usually, conventional PCR is used to characterize OsHV-1 prevalence (Renault et al., 2000, 2004 ; Burge et al., 2006 ; Webb et al., 2007). Our study is the first showing quantitative data over time for the characterization of viral prevalence during a mortality event. This was made possible by the use of real-time PCR quantification recently developed (Pépin et al., 2008). Our study describes the evolution and spread of the viral infection at the individual and the family level. Prior to our study, Pépin et al. (2008) showed that an average number of $1.10^{3}$ copies of viral DNA mg-1 of tissue do not represent an infective status associated with mortality. Similarly low viral loads have been reported for the koi herpes virus (KHV) in asymptomatic fish and it was suggested that they could be associated with latency rather than productive infection (Gilad et al., 
2004 ; Goodwin et al., 2006). In our study, the viral load, in living or dead oysters reached up to $10^{7}-10^{8}$ viral DNA copies $\mathrm{mg}^{-1}$ tissue but was highly variable. High variations in viral DNA quantification between individuals may indicate different stages of viral infection. The detection of a great amount of viral DNA in some living oysters $\left(10^{7}-10^{8}\right.$ copies of viral DNA $\mathrm{mg}^{-1}$ tissue) may represent the final stage of infection before death, in which case detecting such an amount of OsHV-1 DNA may be interpreted as a negative prognostic factor. However, further knowledge of the kinetics of viral infection is still needed. The study of the temporal evolution of the OsHV-1 DNA load in a single adult individual during viral infection would be of great interest. This would require repetitive sampling of a few $\mathrm{mg}$ of mantle tissue from the same individuals, which is a common practice in adult oysters where it does not induce a higher mortality rate (>1\%; Suquet et al., 2009). Attempts to quantify Perkinsus marinus, which affects the eastern oyster $C$. virginica, have previously been made in the water column using a molecular approach (Audemard et al., 2006). Real-time PCR assay appears to be a powerful tool that would be appropriate for investigating the abundance of OsHV-1 DNA in water samples to monitor virus presence in the environment over seasonal changes.

\subsection{Genetically based resistance to OsHV-1 and its transmission}

Our results suggest there is a genetic basis for resistance to OsHV-1 infection in the Pacific oyster. First, our data showed a high variance in the viral prevalence between the 3 full-sib oyster families. This suggests that each group of oysters may be composed of individuals with different degrees of tolerance to the viral infection. Their parental origin may lead to a differential segregation of alleles linked to sensitivity or resistance to mortality and/or OsHV-1 infection. In the $B^{*} X$ family, we could argue that both F1 parents carried alleles linked to the resistance to mortality and/or infection by OsHV-1 whereas, for the $Z^{*} A C$ family, the same alleles were not carried by the parents and were therefore not transmitted to the progeny.

Previous studies suggest that a genetic basis may underlie resistance to OsHV-1 infection in the Pacific oyster. Le Deuff et al. (1996) showed that the geographic origins of parents, in relation to the appearance of the disease, might have influenced the cumulative percentage of mortality in their progeny.

The persistence of OsHV-1 in asymptomatic adults was demonstrated by the detection of viral DNA and proteins, suggesting that OsHV-1 has a high prevalence among adult oysters and may persist in its host after a primary infection (Arzul et al., 2002). The vertical transmission of OsHV-1 through gametes released during experimental crosses, was investigated in another study made over three successive generations of Pacific oysters (G0 and G1 parental oysters, G1 and G2 larvae - Barbosa-Solomieu et al., 2005). Results strengthened the hypothesis of a vertical transmission, although it was not possible to predict the issue of a particular type of cross. The detection of viral DNA in parental oysters did not systematically correspond to a productive infection or result in any successful transmission to the progeny. Moreover, Batista et al. (2007) argue that negative PCR results do not necessarily indicate that oysters are not infected, because when levels of viral DNA in the tissues are low, they may be below the threshold of the detection method.

Other means of viral transmission should be considered. Latent infection in oysters may be reactivated by the water temperature stimulus or other environmental factors allowing the transmission of the virus to the nearest neighbours. Like other herpes viruses, OsHV-1 seems to be able to persist in its hosts (Arzul et al., 2002). Infected oysters may play the role of carriers and reservoirs of the virus, promoting virus transmission from infected to non-infected ones, as previously hypothesized (Le Deuff et al., 1996). Considering this possibility, we decided to examine the seawater in which the oysters were growing in an attempt to see whether OsHV-1 could be detected using real-time PCR in samples collected during the mortality outbreak (day 139 to day 159). The results demonstrated the presence of viral DNA in the seawater around the oysters $\left(1.10^{3}\right.$ to $2.10^{3}$ viral DNA copies. $\left.L^{-1}\right)$. Although this method still requires some technical improvement, real-time PCR assay appears to be a valuable tool for investigating the abundance of OsHV-1 DNA in water samples and could therefore be used to monitor virus presence in the environment over seasonal changes. The detection of viral DNA in sea water samples and the observed variance of viral load among dead and living individuals suggest that (i) sea water may act as a vector in the horizontal transmission of OsHV-1 and (ii) some individuals play a reservoir 
role in the spread of the disease as previously proposed (Arzul et al., 2002). Heavily infected oysters may have been sites of intense viral replication until their death, and virus release from moribund and dead oysters allowed horizontal transmission to living ones. Moribund and dead infected oysters may thus act as a major source of the virus. In our experiment, variation in survival within and between families suggests that such horizontal transmission did not lead to the mortality of newly infected oysters during the study period.

Improved knowledge about transmission of OsHV-1 may lead to practical epidemiological recommendations that would limit the impact of viral infection on the oyster industry. The screening for OsHV-1 in stocks of oysters during their transportation between different geographical zones of culture could help to prevent the spread of the virus. Similarly, larvae and seed produced by hatcheries and nurseries could be screened prior to their transfer to the field. In Maryland and Virginia (USA), the introduction of a non-native species, the cupped oyster Crassostrea ariakensis originating from China, was discussed to overcome the drastic decline of eastern oyster Crassostrea virginica populations due to over-fishing, diseases and habitat destruction in Cheasapeake Bay (Moss et al., 2007). Prior to the introduction, the pathogen survey of $C$. ariakensis and other sympatric oyster species was conducted on samples collected in the PR China, Japan and Korea using molecular diagnostics and histopathology. This study revealed the presence of two Perkinsus species not currently found in USA waters and three particular strains of molluscan herpes viruses. As a result, there is a strong interest in increasing the use of this kind of study prior to any restoration or introduction attempts with oysters or marine bivalves in general. The knowledge gained with the Pacific oyster model can be extended to other species affected by herpes-like viral infections, such as the abalone whose production in Taiwan and in Australia has been affected by massive mortalities over the last few years (Chang et al., 2005; Hooper et al., 2007; Tan et al., 2008).

\section{Acknowledgements}

The authors wish to thank the Ifremer hatchery team in La Tremblade and the nursery team in Bouin, especially Max Nourry, for their technical assistance during the larval and post-larval rearing phases. This work was supported by the EU funded project "Aquafirst" - "Combined genetic and functional genomic approaches for stress and disease resistance marker assisted selection in fish and shellfish" (STREP contract $n^{\circ}$ 513692) - and the Région Poitou-Charentes (CPER). We also want to thank two anonymous referees for the helpful input in their reviews of this paper. Finally, the authors are very grateful to Helen McCombie who edited the English. 


\section{References}

Arzul, I., Renault, T., Thebault, A. and Gérard, A. 2002. Detection of oyster herpesvirus DNA and proteins in asymptomatic Crassostrea gigas adults. Virus Research 84(1-2): 151-160.

Audemard, C., Ragone Calvo, L. M., Paynter, K. T., Reece, K. S. and Burreson, E. M. 2006. Realtime PCR investigation of parasite ecology: in situ determination of oyster parasite Perkinsus marinus transmission dynamics in lower Chesapeake Bay. Parasitology 132: 827-842.

Batista, F. M., Arzul, I., Pepin, J.-F., Ruano, F., Friedman, C. S., Boudry, P. and Renault, T. (2007). Detection of ostreid herpesvirus 1 DNA by PCR in bivalve molluscs: A critical review. Journal of Virological Methods 139(1): 1-11.

Baud, J.P., and Bacher, C. 1990. Use of ground saline water for intensive rearing of Ruditapes philippinarum juveniles in a nursery system. Aquaculture 88: 157-178.

Barbosa-Solomieu, V., Miossec, L., Vásquez-Juárez, R., Ascencio-Valle, F. and Renault, T. 2004. Diagnosis of Ostreid herpesvirus 1 in fixed paraffin-embedded archival samples using PCR and in situ hybridisation. Journal of Virological Methods 119(2): 65-72.

Barbosa-Solomieu, V., Degremont, L., Vazquez-Juarez, R., Ascencio-Valle, F., Boudry, P. and Renault, T. (2005). Ostreid Herpesvirus 1 (OsHV-1) detection among three successive generations of Pacific oysters (Crassostrea gigas). Virus Research 107(1): 47-56.

Beattie, J., Chew, K. and Hershberger, W. 1980. Differential survival of selected strains of Pacific oysters (Crassostrea gigas) during summer mortality. Proceedings of National Shellfish Association 70: 184-189.

Boudry, P., Collet, B., Cornette, F., Hervouet, V. and Bonhomme, F. 2002. High variance in reproductive success of the Pacific oyster (Crassostrea gigas, Thunberg) revealed by microsatellite-based parentage analysis of multifactorial crosses. Aquaculture 204(3-4): 283-296.

Boudry, P., Dégremont, L. and Haffray, P. 2008. The genetic basis of summer mortality in Pacific oyster spat and potential for improving survival by selective breeding in France. In: Summer mortality of Pacific oyster Crassostrea gigas - The Morest Project. Quae Editions, Versailles, France, pp.153-196.

Burge, C. A., Griffin, F. J. and Friedman, C. S. 2006. Mortality and herpesvirus infections of the Pacific oyster Crassostrea gigas in Tomales Bay, California, USA. Diseases of Aquatic Organisms 72(1): 31-43.

Burge, C. A., Judah, L. R., Conquest, L. L., Griffin, F. J., Cheney, D. P., Suhrbier, A., Vadopalas, B., Olin, P. G., Renault, T. and Friedman, C. S. 2007. Summer seed: the influence of oyster stock, planting time, pathogens and environmental stressors. Journal of Shellfish Research 26(1): 163172.

Bustin, S. A. 2000. Absolute quantification of mRNA using real-time reverse transcription polymerase chain reaction assays. Journal of Molecular Endocrinology 25(2): 169-93.

Chang, P. H., Kuo, S. T., Lai, S. H., Yang, H. S., Ting, Y. Y., Hsu, C. L. and Chen, H. C. 2005. Herpes-like virus infection causing mortality of cultured abalone Haliotis diversicolor supertexta in Taiwan. Diseases of Aquatic Organisms 65(1): 23-27.

Cheney, D. P., Macdonald, B. F. and Elston, R. A. 2000. Summer mortality of Pacific Oysters, Crassostrea gigas (Thunberg): initial findings on multiple environmental stressors in Puget Sound. Journal of Shellfish Research 19(1): 353-359.

Cheng, T. C. 1996. Hemocytes: forms and functions. The eastern oyster Crassostrea virginica. Maryland Sea Grant College, College Park. Kennedy, V. S., Newell, R. I. E. and Eble, F.: 299-333. Davison, A. J., Trus, B. L., Cheng, N., Steven, A. C., Watson, M. S., Cunningham, C., Deuff, R.-M. L. and Renault, T. 2005. A novel class of herpesvirus with bivalve hosts. Journal of General Virology 86(1): 41-53.

Dégremont, L., E. Bedier, P. Soletchnik, M. Ropert, A. Huvet, J. Moal, J.-F. Samain and Boudry, P. 2005. Relative importance of family, site, and field placement timing on survival, growth, and yield of hatchery-produced Pacific oyster spat (Crassostrea gigas). Aquaculture 249(1-4) 213-229.

Dégremont, L., Ernande, B., Bedier, E., and Boudry, P. 2007. Summer mortality of hatcheryproduced Pacific oyster spat (Crassostrea gigas). I. Estimation of genetic parameters for survival and growth. Aquaculture 262(1): 41-53.

Fabioux, C., Huvet, A., Le Souchu, P., Le Pennec, M., and Pouvreau, S. 2005. Temperature and photoperiod drive Crassostrea gigas reproductive internal clock. Aquaculture 250, 458-470. 
Friedman, C. S., Estes, R. M., Stokes, N. A., Burge, C. A., Hargove, J. S., Barber, B. J., Elston, R. A., Burreson, E. M. and Reece, K. S. 2005. Herpes virus in juvenile Pacific oysters Crassostrea gigas from Tomales Bay, California, coincides with summer mortality episodes. Diseases of Aquatic Organisms 63(1): 33-41.

Garnier, M., Labreuche, Y., Garcia, C., Robert, M., and Nicolas, J.L. 2007. Evidence for the involvement of pathogenic bacteria in summer mortalities of the Pacific oyster Crassostrea gigas. Microbial Ecology 53, 187-196.

Gilad, O., Yun, S., Zagmutt-Vergara, F. J., Leutenegger, C. M., Bercovier, H. and Hedrick, R. P. 2004. Concentrations of a Koi herpesvirus (KHV) in tissues of experimentally infected Cyprinus carpio koi as assessed by real-time TaqMan PCR. Disease of Aquatic Organism 60(3): 179-87.

Glude, A. 1974. Summary report of the Pacific coast oyster mortality investigations 1965-1972. Proceedings of the Third U.S.-Japan Meeting on Aquaculture.

Goodwin, A. E., Merry, G. E. and Sadler, J. 2006. Detection of the herpesviral hematopoietic necrosis disease agent (Cyprinid herpesvirus 2) in moribund and healthy goldfish: validation of a quantitative PCR diagnostic method. Disease of Aquatic Organism 69(2-3): 137-43.

Goulletquer, P., Soletchnik, P., Le Moine, O., Razet, D., Geairon, P. and Faury, N. 1998. Summer mortality of the Pacific cupped oyster Crassostrea gigas in the Bay of Marennes-Oleron (France). Council Meeting of the International Council for the Exploration of the Sea. Cascais (Portugal).

Harris-Young, L., Tamplin, M. L., Mason, J. W., Aldrich, H. C. and Jackson, J. K. 1995. Viability of Vibrio vulnificus in association with hemocytes of the American oyster (Crassostrea virginica). Applied Environmental Microbiology 61: 52-57.

Hooper, C., Day, R., Slocombe, R., Handlinger, J. and Benkendorff, K. 2007. Stress and immune responses in abalone: Limitations in current knowledge and investigative methods based on other models. Fish \& Shellfish Immunology 22(4): 363-379.

Koganezawa, A. 1974. Present status of studies on the mass mortality of cultured oysters in Japan and its prevention. Proceedings of the Third U.S.-Japan Meeting on Aquaculture, Tokyo, Japan.

Labreuche, Y., Soudan, P., Goncalves, M., Lambert, C. and Nicolas, J. L. 2005. Effects of Extracellular Products from the pathogenic Vibrio aestuarianus strain 01/32 on lethality and cellular immune responses of the oyster Crassostrea gigas. Developmental and comparative immunology 30(4): 367-379.

Le Deuff, R. M., Renault, T. and Gérard, A. 1996. Effects of temperature on herpes-like virus detection among hatchery-reared larval Pacific oyster Crassostrea gigas. Diseases of Aquatic Organisms 24(2): 149-157.

Le Deuff, R. M. and Renault, T. 1999. Purification and partial genome characterization of a herpeslike virus infecting the Japanese oyster, Crassostrea gigas. Journal of General Virology 80: 13171322.

Le Roux, F., Gay, M., Lambert, C., Waechter, M., Poubalanne, S., Chollet, B., Nicolas, J. L. and Berthe, F. 2002. Comparative analysis of Vibrio splendidus-related strains isolated during Crassostrea gigas mortality events. Aquatic Living Resources 15: 251-258.

Le Roux, F., Gay, M., Lambert, C., Nicolas, J. L., Gouy, M. and Berthe, F. 2004. Phylogenetic study and identification of Vibrio splendidus-related strains based on gyrB gene sequences. Diseases of Aquatic Organisms 58(2-3): 143-150.

Lipart, C. and Renault, T. 2002. Herpes-like virus detection in infected Crassostrea gigas spat using DIG-labelled probes. Journal of Virological Methods 101(1-2): 1-10.

Meyers, T. R., Short, S. and Eaton, W. 1990. Summer mortalities and incidental parasitisms of cultured Pacific oysters in Alaska. Journal of Aquatic Animal Health 2: 172-176.

Moal, J., Lambert, C., Pouvreau, S., Le Moullac, G. and Samain, J.F. 2008. Temperature as a risk factor in oyster summer mortality, in: Samain, J.F., McCombie, H. (Eds.), Summer mortality of Pacific oyster Crassostrea gigas - The Morest Project, Eds Quae, Versailles, France, 289-306 pp.

Moss, J. A., Burreson, E. M., Cordes, J. F., Dungan, C. F., Brown, G. D., Wang, A., Wu, X. and Reece, K. S. 2007. Pathogens in Crassostrea ariakensis and other Asian oyster species: implications for non-native oyster introduction to Chesapeake Bay. Diseases of Aquatic Organisms 77(3): 207-223.

Nicolas, J.L., Renault, T., Gagnaire, B., Garcia, C., Garnier, M., Gay, M., Labreuche, Y., Le Roux, F., Miossec, L., Pépin, J.-F. and Saulnier, D. 2008. Oyster summer mortality risks associated with pathogens, in: Samain, J.F., McCombie, H.,Summer mortality of Pacific oyster Crassostrea gigas The Morest Project. Quae Editions, Versailles, France, pp243-287 
Pépin, J.-F., Riou, A. and Renault, T. 2008. Rapid and sensitive detection of ostreid herpesvirus 1 in oyster samples by realtime PCR. Journal of Virological Methods 149(2): 269-276.

Perdue, J.A., Beattie, J.H. and Chew, K.K., 1981. Some relationships between gametogenic cycle and summer mortality phenomenon in the Pacific oyster (Crassostrea gigas) in Washington state. Journal of Shellfish Research 1: 9-16.

Ragone Calvo, L. M., Dungan, C. F., Roberson, B. S. and Burreson, E. M. 2003. Systematic evaluation of factors controlling Perkinsus marinus transmission dynamics in lower Chesapeake Bay. Diseases of Aquatic Organisms 56(1): 75-86.

Renault, T., Cochennec, N., Le Deuff, R. M. and Chollet, B. 1994. Herpes-like virus infecting Japanese oyster (Crassostrea gigas) spat. Bulletin of European Association of Fish Pathology 14: 64-66.

Renault, T. and Lipart, C. 1998. Diagnosis of herpes-like virus infections in oysters using molecular techniques. European Aquaculture Society Special Publication 26: 235-236.

Renault, T., Le Deuff, R. M., Lipart, C. and Delsert, C. 2000. Development of a PCR procedure for the detection of a herpes-like virus infecting oysters in France. Journal of Virological Methods 88(1): 41-50.

Renault, T., Arzul, I. and Lipart C. (2004). Development and use of an internal standard for oyster herpes virus 1 detection by PCR. Journal of Virological Methods 121: 17-23.

Robledo, J. A. F., Pecher, W. T. and Vasta, G. R. 2000. High-throughput isolation of oyster DNA facilitates diagnosis of "Dermo" disease. Qiagen News 5: 15-17.

Ropert, M., Mazurié, J., Bédier, E., Le Coz, F., and Soletchnik, P., 2008. Evaluation of summer mortality risk factors in shellfish farming ecosystems, in: Samain, J.F., McCombie, H., Summer mortality of Pacific oyster Crassostrea gigas - The Morest Project, Quae Editions, Versailles, France, pp1-61

Samain, J.F. and McCombie, H., 2008. Summer mortality of Pacific oyster Crassostrea gigas, The Morest project, Eds Quae, Versailles, France.

Samain, J.-F., Ropert, M., Bedier, E., Soletchnik, P., Mazurié, J., Le Coz, F., Blin, J.-L., Costil, K., Mille, D., Trintignac, P., Boudry, P., Haffray, P., Bacher, C., Grangeré, K., Pouvreau, S., Bourles, Y., Sylvand, B., Misko, P., Gohin, F. and Woerther, P. 2008. A synthesis of the Morest program and recommendations for forecasting and managing oyster summer mortalities, in: Samain, J.F., McCombie, H., (Eds.) Summer mortality of Pacific oyster Crassostrea gigas, The Morest project, Eds Quae, Versailles, France, pp 307-348.

Samain, J.F., Dégremont, L., Soletchnik, P., Haure, J., Bédier, E., Ropert, M., Moal, J., Huvet, A., Bacca, H., Van Wormhoudt, A., Delaporte, M., Costil, K., Pouvreau, S., Lambert, C., Boulo, V., Soudant, P., Nicolas, J.L., Le Roux, F., Renault, T., Gagnaire, B., Géret, F., Boutet, I., Burgeot, T. and Boudry, P., 2007. Genetically based resistance to summer mortality in the Pacific oyster (Crassostrea gigas) and its relationship with physiological, immunological characteristics and infection process. Aquaculture, 268: 227-243.

Soletchnik, P., Faury, N., Razet, D. and Goulletquer, P. 1998. Hydrobiology of the MarennesOleron Bay. Seasonal indices and analysis of trends from 1978 to 1995. Hydrobiologia 386: 131146.

Soletchnik, P., Le Moine, O., Faury, N., Razet, D., Geairon, P. and Goulletquer, P. 1999. Mortalité de I'huître Crassostrea gigas dans le bassin de Marennes-Oléron. Etude de la variabilité spatiale, de son environnement et de sa biologie par un système d'information géographique (SIG). Aquatic Living Resources 12(2): 131-143.

Soletchnik, P., Ropert, M. Mazurié, J., Fleury, P.G. and Le Coz, F. 2007. Relationships between oyster mortality patterns and environmental data from monitoring databases along the coasts of France. Aquaculture 271, 384-400.

Suquet, M., de Kermoysan, G., Gonzales Araya, R., Queau, I., Lebrun, L., Le Souchu, P. and Mingant, C. Anesthesia in Pacific oyster, Crassostrea gigas. Aquatic Living Resources. In press

Tan, J., Lancaster, M., Hyatt, A., van Driel, R., Wong, F. and Warner, S. 2008. Purification of a herpes-like virus from abalone (Haliotis spp.) with ganglioneuritis and detection by transmission electron microscopy. Journal of Virological Methods 149(2): 338-341.

Taris, N., Ernande, B., McCombie, H. and Boudry, P. 2006. Phenotypic and genetic consequences of size selection at the larval stage in the Pacific oyster (Crassostrea gigas). Journal of Experimental Marine Biology and Ecology 333: 147-158. 
Webb, S. C., Fidler, A. and Renault, T. 2007. Primers for PCR-based detection of ostreid herpes virus-1 (OsHV-1): application in a survey of New Zealand molluscs. Aquaculture 272: 126-139. 
Table 1. Qualitative data for OsHV-1 detection and associated prevalence obtained using real-time PCR in dead and living oysters of the three studied oyster families.

$\mathrm{N}=$ number of samples analysed by real-time PCR.

\begin{tabular}{|c|c|c|c|c|c|}
\hline Status & Family & $\mathbf{N}$ & Positive & Negative & $\begin{array}{c}\text { Prevalence } \\
\text { (\% of } \\
\text { infected } \\
\text { individuals) }\end{array}$ \\
\hline \multirow{3}{*}{$\frac{\frac{\mathscr{n}}{\pi}}{\frac{\sigma}{2}}$} & $B^{*} X$ & $0^{*}$ & & & \\
\hline & $R^{*} \mathbf{O}$ & 150 & 142 & 8 & 94.7 \\
\hline & $Z * A C$ & 150 & 143 & 7 & 95.3 \\
\hline \multirow{3}{*}{ 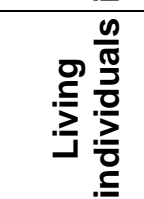 } & $B^{*} X$ & 96 & 9 & 87 & 9.4 \\
\hline & $R^{*} \mathbf{O}$ & 107 & 89 & 18 & 83.2 \\
\hline & $Z^{*} A C$ & 102 & 81 & 21 & 79.4 \\
\hline
\end{tabular}

${ }^{*}$ No mortality recorded in the $B^{*} X$ family

Table 2. Viral load quantification in oyster samples using real-time PCR, expressed as viral DNA copy number $\mathrm{mg}^{-1}$ of fresh tissue, in dead, living and surviving oysters.

\begin{tabular}{|c|c|c|c|c|c|c|c|}
\hline Status & Family & $\begin{array}{c}\text { Cumulative } \\
\text { percentage of } \\
\text { mortality } \\
(n=1500)\end{array}$ & $\begin{array}{c}\text { Number of } \\
\text { individuals } \\
\text { analysed }\end{array}$ & $\begin{array}{l}\text { Minimal } \\
\text { individual } \\
\text { viral load }\end{array}$ & $\begin{array}{c}\text { Maximal } \\
\text { individual } \\
\text { viral load }\end{array}$ & $\begin{array}{l}\text { Average viral } \\
\text { load }\end{array}$ & $\begin{array}{l}\text { Standard } \\
\text { error }\end{array}$ \\
\hline \multirow{3}{*}{ 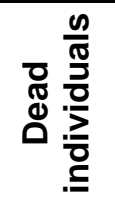 } & $B^{*} X$ & 1.2 & 0 & ND & ND & ND & ND \\
\hline & $\mathrm{R}^{*} \mathbf{O}$ & 38 & 150 & 5 & $2.9510^{07}$ & $2.0410^{06}$ & $3.8610^{06}$ \\
\hline & $Z^{*} A C$ & 49 & 150 & 0 & $4.8410^{08}$ & $1.1410^{07}$ & $4.6610^{07}$ \\
\hline \multirow{3}{*}{ 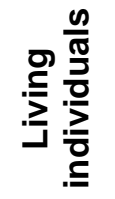 } & $B^{*} X$ & - & 96 & 0 & $3.4010^{03}$ & $2.5010^{02}$ & $1.3410^{03}$ \\
\hline & $\mathrm{R}^{\star} \mathrm{O}$ & - & 107 & 0 & $6.5710^{07}$ & $1.0810^{05}$ & $6.7010^{06}$ \\
\hline & $Z^{*} A C$ & - & 150 & 0 & $1.1010^{08}$ & $1.7110^{05}$ & $1.1110^{06}$ \\
\hline \multirow{3}{*}{ 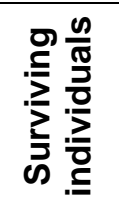 } & $B^{*} X$ & - & 150 & 0 & $2.3510^{03}$ & $1.0210^{02}$ & $2.4810^{02}$ \\
\hline & $\mathrm{R}^{\star} \mathrm{O}$ & - & 150 & 0 & $1.7110^{03}$ & $3.3410^{02}$ & $1.4710^{02}$ \\
\hline & $Z^{*} A C$ & - & 150 & 0 & $2.4610^{02}$ & $1.8610^{02}$ & $2.5410^{02}$ \\
\hline
\end{tabular}

ND: no individuals were analysed 


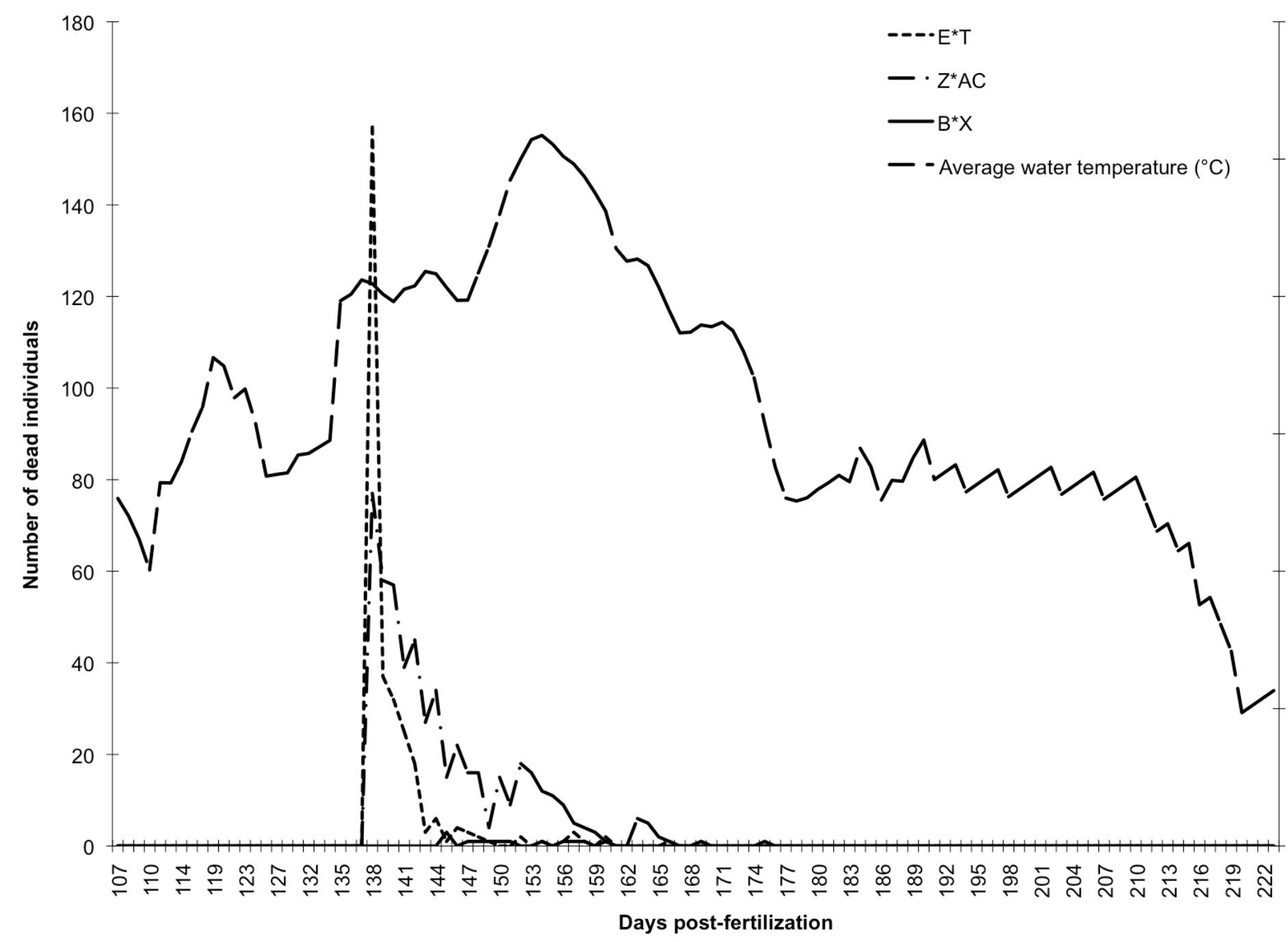

Figure 1. Kinetics of mortality during the outbreak in summer 2006, shown with concomitant seawater temperature $\left({ }^{\circ} \mathrm{C}\right)$ 

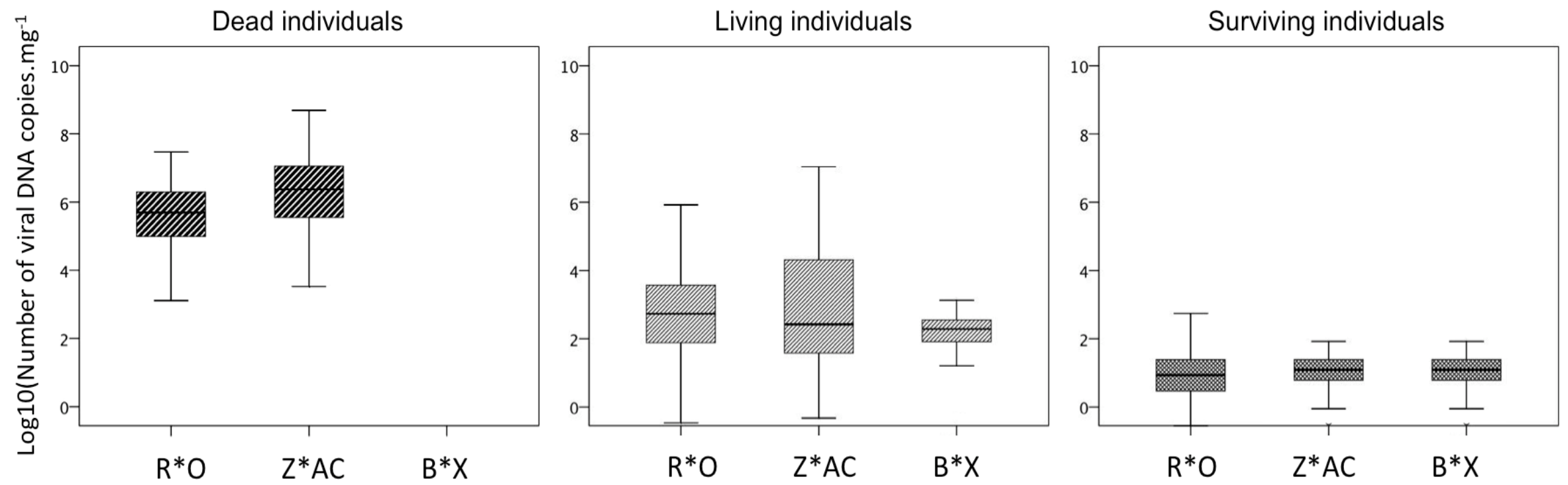

Figure 2. Box-plots representing the variance in mean viral quantification between families and sample types 